\title{
Railroad Promotion and Economic Expansion at Council Bluffs, Iowa, 1857-1869
}

Sidney Halma

PRIOR TO 1857 THE UNITED STATES ENJOYED increasing prosperity. Gold discoveries in the Far West preceded the gold rush of 1849 and encouraged migration from eastern cities. Western movement accelerated demands for transportation, resulting in rapid railroad expansion, speculation in real estate, and a general scramble for quick fortunes. Speculation was particularly common in outfitting centers that engaged in the lucrative business of supplying emigrants. Overexpansion led to financial panic in 1857 .

The first sign of an impending financial crash in one of these outfitting centers, Council Bluffs, was the closing of the Benton banking house in September. A prominent citizen, Dexter C. Bloomer, recalled the event: "All my money was in Benton's bank which failed." 1 A number of other residents suffered similar losses in 1857. Benton made earnest and persistent efforts to meet his obligations but was unable to repay and eventually lost his homestead. The collapse of one after another bank in nearby Nebraska rendered their bills worthless. ${ }^{2}$

Of the four banking firms in Council Bluffs at that time, all but the Officer \& Pusey firm dealt extensively with Nebraska currency, which circulated locally in large quantities. Prior to 1855 , the circulating medium throughout the Council Bluffs region had been confined primarily to gold or silver specie. Eagles and double eagles were abundant; bank bills were the exception rather Archives.

'D. C. Bloomer, "Commonplace Book," Iowa Department of History and

${ }^{2}$ D. C. Bloomer, "Notes on the Early History of Pottawattamie County, Annals of Iowa, First Series, X (July, 1872), 185-186. 
than the rule. The Iowa Constitution of 1846 prohibited banks from issuing paper money. ${ }^{3} \mathrm{~A}$ number of easterners and Iowans incorporated "wildcat" banks across the Missouri River in the Territory of Nebraska. This paper money rapidly filled the vacuum caused by the drain of specie at Council Bluffs.

The Council Bluffs banking and real estate firm of Baldwin and Dodge likewise was seriously hurt by the collapse of banks and decline in land values. Town lots depreciated in value; prices fell lower and lower. Lots in Council Bluffs selling in 1856-7 for $\$ 3,000-\$ 4,000$ could hardly be sold for $\$ 750-\$ 1,000$ in $1860 .^{4}$ Money became very scarce. Council Bluffs residents were literally without money for some time. People resorted to trade and barter and wore their old clothes. Merchants issued pieces of paste-board which were good for five, ten, and fifty cents in merchandise. Farmers went ragged and burned corn for fuel.

The full impact of the Panic of 1857 was not felt in Council Bluffs because of the yearly emigrant trade. Emigrants continued to move across Iowa on their way west and because it was an outfitting center, the town continued to reap the benefit of active trading. Merchandise sold freely for cash, and the farmers found a good market for corn and wheat. ${ }^{5}$

Fortunately in 1858 the announcement that gold had been discovered in the Colorado region vaguely known as Pike's Peak once more brought large numbers of outfitters to Council Bluffs. The news of the discovery of gold in Cherry Creek near Pike's Peak was at once circulated by travelers and newspapers. The Iowa Weekly Citizen of Des Moines was one of the first newspapers to publicize the Cherry Creek discovery. The newspaper reported that two men with "inferior implements washed out $\$ 600$ in one week. ..." The Council Bluffs Nonpareil followed three days later with the banner:

Pike's Peak Gold Diggins! Eureka! Eureka! Gold Mines Within 500 miles! The Best Route Thither! The Yellow Fever Spreading Rapidly! The Only Antidote-Pick and Shovel!!!'

${ }^{3}$ Ruth A. Gallaher, "Money in Pioneer Iowa, 1838-1865," Iowa Journal of History and Politics, XXXII (January, 1934), 20-21.

Bloomer, op. cit., X (July, 1872).

'Ibid., pp. 191-192.

- Des Moines Iowa Weekly Citizen. September 8, 1858.

'Council Bluffs Nonpareil. September 11, 1858. 
Newspapers undoubtedly exaggerated these reports about the gold discoveries because "the Panic of 1857 was depressing business and a gold rush would restore prosperity to pioneer towns where miners bought supplies." 8

Attempting to substantiate rumors about the gold rush, the Council Bluffs newspaper published accounts stating that the gold discovery had been officially confirmed by James W. Denver, Governor of the Kansas Territory, in a letter to the Secretary of the Interior. ${ }^{9}$ For the next several years much space in the Council Bluffs newspaper was devoted to articles on the new gold regions and the best routes to them. Council Bluffs, Nebraska City, and St. Joseph competed for the outfitting business. The press in each town advertised that the best and most direct route to the gold fields lay through its limits. The Council Bluffs Nonpareil published an elaborate map of the road from Council Bluffs to the Cherry Creek gold mines. Several Council Bluffs' residents responded to the "gold fever." Samuel Curtis, a prominent citizen, was among those who joined the throng headed for the gold fields. Curtis served as a correspondent for the Nonpareil, which published his letters reporting favorable conditions. ${ }^{10}$

By the spring of 1859 , reports to the contrary alleged that the entire rush was a "humbug" and that it was ridiculous to believe a fortune could be made quickly. The Burlington Hawkeye, published in a rival outfitting center, pronounced the whole story about the discovery of gold on Cherry Creek a wicked deception and fraud. ${ }^{11}$ Disillusioned gold seekers influenced many to return. Hundreds of returning emigrants recrossed the Missouri, highly indignant at the merchants and newspapermen of Council Bluffs and rival towns, and charged that they had been misled. Threats of vengeance were sometimes heard, leading the press and businessmen to fear for their safety and property. ${ }^{12}$ The Council Bluffs Bugle attempted to learn the truth of the so-called

-Ray Allen Billington, Westward Expansion (New York: Macmillan, 1967), pp. 619-620.

${ }^{9}$ Council Bluffs Nonpareil, October 9, 1858. 192.

${ }^{10} I$ bid., September 18, October 16, 1858. Bloomer, op. cit., X (July, 1872),

"Bloomer, op. cit., X (July, 1872), 193-194.

${ }^{12}$ Nathan P. Dodge, "Early Emigration Through and to Council Bluffs," Annals of Iowa, Third Series, XVIII (January, 1932), 167-169. 
gold discovery, but stated that no returnees had been as far as the mines.

We are fully persuaded that the return stampede has been caused by speculation beyond Fort Kearney, those who have turned the Emigration back-bought their outfits for almost nothing and are making a big speculation out of their frauds, falsehoods and lying. . . .

Emigrants are told all kinds of stories. Some say that the reports of the Mines are gotten up by persons in the frontier towns for the purpose of selling outfits ... such assertions, as far as we are concerned, are unqualifiedly false. . . . ${ }^{13}$

The reports in the newspapers became so conflicting that three eastern editors, Horace Greeley, Henry Villard, and Albert $D$. Richardson, went to the region to report the facts for their newspapers. On June 9,1859 , these three newspapermen signed a widely publicized statement from Gregory's Diggings which stated that, while there was gold in this region, mining was a business that required "capital, experience, energy, endurance. . . ." The report enumerated the successes of several individuals in that area and stated that many others had left too hastily. ${ }^{14}$ The report, coming in the midst of the 1859 gold rush, may have discouraged some potential miners, nevertheless, Council Bluffs saw hordes of hopeful '59ers. ${ }^{15}$ Approximately 15,000 people passed through in 1859 , some of whom probably bought provisions at Omaha.

The Council Bluffs press made further attempts to destroy the apparent myth of the humbug by sending a correspondent to the Colorado gold fields to verify the findings. William H. Kinsman, a correspondent for the Nonpareil, walked the entire distance from Council Bluffs to Cherry Creek. He reached the mining region in early June, and sent back a record of his observations. His optimistic reports produced further excitement in Council Bluffs and points east. ${ }^{16}$

The renewed emigration brought a revival of trade at Council Bluffs. By March of 1859 a "steady tide of hoofs and horns and covered wagons" was passing through the streets, and leaving

${ }^{13}$ Council Bluffs Bugle, May 18, 1859.

${ }^{14}$ Des Moines Iowa Weekly Citizen. June 29, 1859.

is Council Bluffs Weekly Nonpareil, June 11, 1859.

${ }^{10}$ Bloomer, op. cit., X(April, 1872), 193-194. 
daily for Colorado. Every stage from the east brought passengers, and five or six steamers unloaded from fifty to seventy-five "Peakers" weekly. By April these numbers had grown to hundreds daily-most of them from the upper Mississippi Valley. One prospector observed that Council Bluffs was "not a very inviting looking place it is situated between two bluffs one main street only and a very few good buildings. Streets and ravines crowded with teams and emigrants." 17 While some camped nearby, quite a few companies disregarded the inclement weather and advice of "those who knew" and departed immediately.

Although the rush was over in June, the effect of this banner year upon Council Bluffs was noteworthy. Several large hotels catered to the emigrants; outfitters increased in numbers, eleven advertising in one newspaper; a "horse-railroad" was organized to run the three miles from the city to the landing; and a porkpacking plant was established.

The decade of the sixties brought another great westward movement. Farmers destined for the Far West were generally better equipped than the emigrants who had headed for Colorado. Nevertheless, Council Bluffs merchants did a brisk business, since their advertising was designed to create a felt-need for new products. Publicity agents promised the public an abundance of reasonably priced goods:

$\because$ articles can be purchased here cheaper than at any other town or city in Jowa. We have mills in the city that can manufacture from two to three hundred sacks of flour daily, and the mills in the county within four miles to the city can make as many more. There is an abundance of wheat to be manufactured - enough to supply all the wants of the country and emigration, and a large surplus for shipping. ${ }^{18}$

Publicity centered around the superiority of the Mormon Trail, recommended as the "natural highway" to the mines. The estimated 25,000 people who had passed over the Mormon Trail previously could not be wrong. In 1860, according to emigrant guidebooks, the trail boasted a shorter route, abundant supplies of wood and water, a well-protected and settled route up to $\mathrm{Ft}$.

${ }^{17}$ Kenneth F. Millsap, (ed.), "Romanzo Kingman's Pike Peak Journal, 1859," Iowa Journal of History and Politics (January, 1950), 67-69.

${ }^{10}$ Council Bluffs Weekly Bugle. February 29, 1860. 
Kearney, and easily-crossed rivers. ${ }^{19} \mathrm{~A}$ map of the region between the Missouri and the Rockies, which showed Council Bluffs closer to the mines than it actually was, ran for weeks in the Bugle. A detailed "Table of Distances" informed the emigrant of every station, ferry, and bridge, and of wood and water along the entire route. In a more spectacular vein, a traveling artist exhibited 10,000 -feet of canvas paintings of Council Bluffs, Omaha, the overland trail and the mines in both towns before taking them east on a tour. ${ }^{20}$

Inducements such as these encourgaged the arrival of increasing numbers of emigrants. By April and May some fifty wagons were leaving for the prairies daily, and each week some 1,000 emigrants arrived by steamer, wagon, or stage. ${ }^{21}$ The two steam ferries, each capable of carrying twelve teams per trip and making from twenty to thirty trips each day, were kept busy crossing the "Big Muddy!" Livestock in great droves accompanied many wagons bound for California, Oregon, and the Rocky Mountain territory.

The emigrant of the sixties made a somewhat different impression than his counterpart of the late fifties. He was, noted an observer, generally "of the wealthy class, and for sobriety, morality and general good behavior is not surpassed by the resident population. . . . Out of the vast crowd which has passed through, we have not seen but one man who was any worse for liquor." 22

Although Council Bluffs employed publicity agents, a local editor denied sending "runners" to the states to the east, as he alleged other outfitting towns did. He claimed that this was unnecessary because the emigrants generally followed the most accessible routes such as the North Platte Route. Statistics reported by the company owning the two steam ferry boats supported this claim. For the week ending April 24, 1860, 514 emigrants were counted. The total for the six weeks ending May 26 was 1,526 wagons and 4,602 men. Despite these incomplete figures, it is probable that Council Bluffs did get "four-fifths of all the emigration from Iowa, Illinois, Indiana, and States East and North of

${ }^{19} \mathrm{Ibid}$.

${ }^{20}$ Council Bluffs Weekly Nonpareil, February 18, 1860.

${ }^{21}$ Council Bluffs Weekly Bugle, April 18, May 9, 1860.

${ }^{22}$ Ibid., May 9, 1860. 
them . ." totaling between 10,000 and 15,000 . Seventy-nine steamer arrivals prior to August 1 and more than $\$ 21,000$ collected for freighting services indicated that business was good. ${ }^{23}$

The trend established in 1860 continued the following year. Streets were jammed with wagons. Steamboat arrivals became too regular to be news. Emigrants destined for the Far West, particularly California, appeared to dominate the crowds. Westward movement did not cease during the Civil War years. Economic opportunities continued to beckon emigrants. Not only were gold and silver tantalizing, but also the climate, rich soil, and commercial possibilities drew the restless to western territories. Emigration through Council Bluffs was unabated in 1863, partly due to the disruption caused by the war and fear of the draft. ${ }^{24}$ Dexter Bloomer recalled that the emigrants passing through Council Bluffs in 1863 were "almost uniformly opposed to the prosecution of the war and to the policy of the government in putting down the rebellion. ${ }^{25}$

As was customary, the outfitting houses did a heavy business despite rumors circulated by eastern outfitting towns that prices were higher at Council Bluffs. One emigrant buying supplies at Council Bluffs recorded in his diary: "Council Bluffs is not a very large place, but is a very busy one. We are surprised at the amount of business done here and at Omaha." ${ }^{26}$ Many newcomers were lured by the prosperity of an emigration market and settled in the Council Bluffs area.

Railroad propaganda intended to attract travelers to Council Bluffs was deflated by the Panic of 1857. An important event, however, helped to rekindle the interest in railroad construction -Abraham Lincoln's visit to Council Bluffs in the summer of 1859. After a campaign trip to Kansas, Lincoln, accompanied by Secretary of State O. M. Hatch of Illinois, visited Council Bluffs. Some have speculated as to why Lincoln came to Council Bluffs. ${ }^{27}$ One explanation is that he came to see two families there whom

${ }^{23}$ Ibid., May 9, August 8, 1860.

${ }^{24}$ Robert G. Athearn, "Across the Plains in 1863: The Diary of Peter Winne," Iowa Journal of History and Politics, XLIX (July, 1951), $221 \mathrm{ff}$.

${ }^{25}$ Bloomer, op. cit.. XI (April, 1873), 424.

${ }^{26}$ Athearn, op. cit.

27"“The Visit of Abraham Lincoln to Council Bluffs," Annals of Iowa. Third Series, IV (July, 1900), 460-461. 
he had known in Springfield, Illinois-the Pusseys and the Officers. A second explanation involved real estate. Norman Judd, manager of Lincoln's debates with Douglas, had asked Lincoln for a loan of $\$ 3,000$, and as security, offered seventeen choice lots in Council Bluffs. It is reasonable to suppose that Lincoln took advantage of the proximity to lowa during his campaign trip to examine the real estate offered by Judd. Others have pointed to Lincoln's desire to study the railroad question in terms of a proposed transcontinental route-passing across western Iowa and eastern Nebraska. ${ }^{28}$ Grenville M. Dodge, a surveryor for the Chicago and Rock Island Railroad, discussed this possible route with Lincoln.

Dodge recommended the $42 \mathrm{~d}$-parallel route because it was the most practical and economical. He felt Council Bluffs was the logical starting place because the railroads had been building from Chicago to that point. As far as Lincoln was concerned, the attraction of the 42d-parallel route was perhaps enhanced by the fact that Judd owned Council Bluffs real estate and was asking him for a loan of $\$ 3,000$ on it. ${ }^{29}$

Speculation aside, the most significant aspect of Lincoln's trip to Council Bluffs was his unofficial designation of that city as the terminus of a future transcontinental railroad. He was escorted to a high bluff on the north edge of town from where he could see ten miles north, ten miles south, and five miles west across the Missouri River. His comment on this occasion will long be remembered in Council Bluffs: "Not one, but many roads will some day center here." ${ }^{30} \mathrm{~A}$ newly generated interest in railroad projects was evidenced by a boundless energy, and a fight by its citizens, during the mid sixties, to make Council Bluffs the leading railroad center of the West.

II

During the 1860s Council Bluffs asserted itself as a leading

${ }^{20}$ Glenn Chesney Quiett, They Built the West: An Epic of Rails and Cities (New York: Cooper Square Publishers, 1965), pp. 3-12.

${ }^{29}$ Grenville M. Dodge, How We Built the Union Pacific Railway (Washington: Government Printing Office, 1910), pp. 47-49; Quiett, op. cit., p. 6.

${ }^{30}$ J. R. Perkins, Trails, Rails, and War (Indianapolis: The Bobbs-Merrill Company, 1929), pp. 46-50; Carl Sandburg, Abraham Lincoln: The Prairie Years, II (New York: Harcourt, Brace \& World, Inc. 1926), 200. 
outfitting town and looked with scorn on its "paper town" rivals. It was no longer necessary to pamper and lure emigrants. The emigrant population was basically comprised of foreigners and farmers with families. Wagons were loaded with household items and furniture, while farm machinery was attached to the back axle. Stovepipes often penetrated the canvas tops, and the smell of beefsteak at mealtime tantalized passers-by. Cows, calves, sheep, and barking dogs followed behind. ${ }^{31}$ "Streets full of wagons and emigrants. Never saw the like. Most all headed for Idaho," wrote Bloomer. ${ }^{32}$ Emigrants were able to buy supplies ranging from wagons and oxen to frying pans. Once the emigrants left Council Bluffs, they experienced additional difficulty in traveling. One emigrant on his way to Idaho recalled these hardships:

.. getting across the Missouri River from Council Bluffs to Omaha, the kinds and degree of discomfort were unspeakable. . . The ferry boat was flat, rude, unclean, more like a raft than a boat; the approach to it on the Iowa side was a steep band of sticky, slippery, black mud, down which we all walked or slid-as best we could, our baggage and blankets being pushed or hurled after us in indiscriminate confusion. ${ }^{33}$

Newspaper coverage of emigration was overshadowed by news of railroad advancements and celebrations. However, emigrant guidebooks boasted of Council Bluffs' assets:

Council Bluffs ... does as much business as any city on the eastern border of the state containing three times the number of inhabitants. . . . And when one of our heavy houses fails to make sales of a thousand or more dollars a day, the proprietors begin to look blue and say, 'Times are dull-nothing doing. ${ }^{34}$

In addition to outfitting the overland travelers, Council Bluffs residents worked toward more amitious goals: to become the leading railroad center of the Northwest, serving the needs of larger groups of emigrants moved by trains to western lands. ${ }^{35}$

3'Oscar O. Winther, The Transportation Frontier, Trans-Mississippi West, 1865-1890 (New York: Holt, Rhinehart and Winston, 1964), p. 17.

${ }^{32}$ Bloomer Diary, April 25, 1864.

${ }^{33}$ Nathan P. Dodge, "Early Emigration Through and to Council Bluffs," $A n$ nals of Iowa, Third Series, XVIII (January, 1932), 175-6.

${ }^{34}$ W. S. Burke, An Outline History of Council Bluffs and its Railroads (Chicago: Horton \& Leonard, 1867).

${ }^{35}$ Levi O. Leonard and Jack T. Johnson, A Railroad to the Sea (lowa City: Midland House, 1939), pp. 83-4. 
Residents launched an impressive propanganda campaign, hoping to attract various railroads to the city. They campaigned through two newspapers-the Bugle and the Chronotype, papers of different political persuasions that nevertheless agreed on the benefits of railway expansion to Council Bluffs. The press capitalized on Council Bluffs' reputation as an outfitting center and suggested that railroads be constructed along this "natural highway" to the west.

As inducements to railway companies, local residents voted bonds, donated land and money, and actually provided free labor to speed the completion of the various lines into their city. The effectiveness of the propaganda combined with financial inducements prevented rival towns from gaining importance as railroad centers. Celebrations and land-breaking ceremonies instilled a high level of interest among the townspeople, and served as springboards for promotion of Council Bluffs. Newspapers publicized these events, attempting to attract the attention of eastern financiers, new residents, and employees. Yet, despite all the talk about railroads, Council Bluffs did not obtain railroad connections before 1867. Until that date it relied on the traditional means of communication and transportation-stages, steamboats, and hacks.

Realization of a transcontinental railroad was an important event in Council Bluff's development. When Asa Whitney, New York businessman and Oriental trader, petitioned Congress in 1845 to construct a transcontinental railroad, the idea had provoked much discussion. Whitney proposed that Congress grant a sixty-mile strip between Lake Superior and Oregon to any company willing to build. Expansionist movements of the forties and fifties, the Mexican War, the discovery of gold in California and Colorado, all contributed to a favorable governmental response.

Among the problems faced by promoters of the transcontinental railroad was the method of financing and selecting a route. Some advocated financing the railroad by private means; others recommended a minimum of government assistance. The magnitude of the project finally convinced railroad promoters that government aid would be an absolute necessity.

Sectional considerations influenced the debate over the route. 
Southerners clamored for a route favoring their interests-a line either along the Butterfield Overland mail route or one following the Canadian or Red Rivers. Northerners favored a route through South Pass. They pointed to the commercial importance of Chicago, and the influx of population into Minnesota and surrounding territory, making a northern route more desirable. By 1860 , public support for a Pacific railroad was sufficient to warrant a railroad plank in the Republican platform declaring "that the Federal Government ought to render immediate and efficient aid in its construction." ${ }^{36}$ It was not until the Southerners left Congress that action on a railroad bill was possible. In the face of an actual war situation, the theory arose that a railroad was a military necessity. Besides, considering the large war expenditures, the cost of financing a railroad seemed minimal.

In 1858 , Congress had authorized a committee to study the feasibility of a Pacific railroad. Upon the committee's recommendations, the second session of the Thirty-sixth Congress took action on a Pacific Railroad bill. President Lincoln felt that the Union Pacific Railroad was a military necessity and was essential to keep the Pacific Coast (California) in the Union. The measure finally sent to the President was a compromise because it attempted to satisfy the various special-interest groups and the demands of a growing railroad lobby.

The act stipulated that the government form a Union Pacific Corporation which would be given ten sections of land and receive a grant of $\$ 16,000$ for every mile of track it laid. The subsidy was increased to $\$ 32,000$ and $\$ 48,000$ per mile for foothills and mountains, respectively. The Union Pacific Company was required to raise sufficient capital to build the first forty miles, after which the subsidy would start. ${ }^{37}$ The specific location of the line was to be decided by competent engineers when the route was defined in general terms. The President was expected to fix the eastern terminus. Lincoln, recalling his interview with Grenville Dodge at Council Bluffs in 1859, summoned him to Washington for a con-

\footnotetext{
${ }^{36}$ Jack T. Johnson, Peter Anthony Dey (Iowa City: State Historical Society, 1939, pp. 83-4.

"Jay Monaghan, The Overland Trail (Indianapolis: The Bobbs-Merrill Company, 1947), pp. 393-4. James McCague, Moguls and Iron Men (New York:
Harper \& Row, 1964), pp. 31-33.
} 
ference. After carefully studying a report made by engineer Peter A. Dey of possible routes west of the Missouri River, Lincoln asked Dodge, who had conducted similar surveys, to help him make a decision. Dodge said that "after his interview with me, in which he showed perfect knowledge of the question, and satisfying himself as to the engineering questions that had been raised, I was satisfied he would locate the terminus at or near Council Bluffs." ${ }^{38}$

Other factors influencing Lincoln's decision are obscure. Lincoln may have been influenced by his friend, Norman B. Judd, who had nominated him for President at the Republican convention in Chicago. Judd owned real estate in Omaha which he hoped to develop. In addition, Lincoln held a vested interest in seventeen lots of land at Council Bluffs, and a railroad terminus in the vicinity would enhance the value of this property. Lincoln issued his first order on November 17, 1863:

I, Abraham Lincoln, President of the United States, do hereby fix so much of the western boundary of the State of Iowa as lies between the north and south boundaries of the United States township within which the city of Omaha is situated as the point from which the line of railroad and telegraph in that section mentioned shall be constructed. ${ }^{39}$

What point specifically did the President have in mind? In his proclamation he may have meant to designate Council Bluffs as the eastern terminus; however, his description does not specifically define that city. The managers of the Union Pacific favored Omaha and began utilizing that area for supply depots for the construction crews and the engineering corps. One historian pointed out that "even in its youth, Omaha was a real center of transportation." ${ }_{40}$

After the celebration marking the beginning of construction, Union Pacific officials asked Lincoln for a new order since the first order was not specific enough. Lincoln complied with the request and issued the second executive order on March 7, 1864.

I, Abraham Lincoln, President of the United States, do, upon the application of said company, designate and establish such first-named point on the eastern boundary of the State of lowa east of and opposite to the

${ }^{38}$ Dodge, How We Built the Union Pacific Railway, p. 57; McCague, op. cit., pp. 70-71.

${ }^{39}$ Ibid., p. 51.

${ }^{40}$ Johnson, op. cit., p. 107. 
east line of section 10 , in township 15 south, of range 13 east, of the sixty principal meridian in the Territory of Nebraska. ${ }^{11}$

Although the second executive order designated the geographic area where the Union Pacific was to originate, it did not pinpoint the location. Omaha's claim to the eastern terminus was backed by Union Pacific officials, while Council Bluffs residents believed that both executive orders referred to their town without specifically naming it. Besides, wasn't one of their own residents, Grenville Dodge, waging a battle on their behalf? Council Bluffs residents were assured that their city would be the "star of the Northwest," as its leaders had predicted before the Panic of 1857.

In the period before the Civil war, Council Bluffs residents had become suspicious of railroads. This suspicion stemmed from a fiasco with the Mississippi and Missouri Railroad. After the company's organization in December of 1852 , promoters had solicited "local aid." Subsequently, $\$ 300,000$ was pledged in bonds to the $M \& M$ company. In return, the $M \& M$ had agreed to build east from Council Bluffs, but only four miles were graded at a cost of $\$ 4,000$. Soon after, the operations were suspended, and the remaining $\$ 296,000$ was never accounted for. The panic of 1857 suspended all operations.

A renewed interest in railroads occurred in the mid $1860 \mathrm{~s}$ when residents realized the financial and commercial benefits to be gained from the railway ties between their city and St. Louis and Chicago. With the assurance that a transcontinental railroad was to be constructed west from the Missouri River, eastern railroads competed to link their lines to the trunk line. Council Bluffs, strategically located in this respect, plunged into an exhausting campaign to attract eastern railroads. A railroad convention was held on May 19, 1858 at Council Bluffs to discuss a year-round supply route between St. Louis and Council Bluffs and to promote the construction of a railroad from Council Bluffs to St. Joseph, Missouri. Four Iowa counties, two Nebraska counties, and three Missouri counties sent delegates to the convention. Since it was largely a local effort, financing of the project depended upon local aid. Residents of Council Bluffs and Pottawattamie County voted bonds and gave the title to a right of way

"Dodge, How We Built the Union Pacific Railroad, p. 51. 
through the county. The company's charter, granted by the State of Iowa in July, 1858, authorized the company to build "from Council Bluffs to some point on the Missouri State line to connect with a railroad from St. Joseph to said line." Unfortunately war abruptly halted building plans. ${ }^{42}$

At a railroad convention in St. Louis in 1865, the directors of the Council Bluffs and St. Joseph Railroad engaged a noted engineer, Willis Phelps of Massachusetts, to complete their line. In order to obtain Phelps' services, the directors practically made him the proprietor of the road.

Early in 1866, the directors of the railroad predicted that cars would begin running to Pacific City, Mills County by July, and that the entire road would be completed by September. The early completion depended in part on the availability of the necessary timber for ties and bridges. The editor of the Bugle assisted the work of Willis Phelps:

Citizens along the line should be liberal towards the contractor in furnishing ties and other timber. They should bear in mind that the high price paid for ties by the Pacific Railroad Company, will not and cannot be paid by the contractor on this road. . .. ${ }^{43}$

Residents proved to be generous and accommodating. The money required for construction-the cost of labor, provisions, and materials-had been raised in Pottawattamie County. From fifty to a hundred teams owned by people in and around Council Bluffs assisted in hauling iron to complete the road. Neighboring residents of Mills and Fremont counties, outside the mainstream of overland travel, were not as helpful.

Despite Phelps' predictions, there was still no locomotive in Council Bluffs or western Iowa by August, 1866. A new promise was made stating that Council Bluffs would be linked to St. Louis, via the Hannibal and St. Joseph Railway by the first of June, 1867. The editor of the Nonpareil was jubilant.

Dinna ye hear the whistle blow? The advance guard of the Council Bluffs and St. Joe Road is only three and a half miles from town. . . . Can't we get some kind of demonstration next week to celebrate the coming of the first train into Council Bluffs? . . . This is an event we have labored and waited and prayed for, these many years, and it should not be permitted now to pass by in silence. ${ }^{44}$

${ }^{42}$ Genevieve Powlinson Mauck, "The Council Bluffs Story," The Palimpsest,

XLII (September, 1961), 416-417.

${ }^{43}$ Council Bluffs Bugle, December 7, 1865.

${ }^{4}$ Council Bluffs Nonpareil. December 13, 20, 1866. 
Floods and high water during the spring and summer, the slow movement of iron and other supplies from the east, and limited capital meant another delay.

Finally, on January 9, 1867, the Council Bluffs and St. Joseph Railroad was formally opened to Bartlett, Fremont County, about twenty-five miles south of Council Bluffs. A number of residents reveled in their first ride. The editor of the Bugle encouraged his readers to take a similar adventure. "It will pay any man who is housed up during the busy months, to take a trip over this road, and look at the vast fields o beautiful, luxurient corn, wheat and oats." "45 With the completion of the Council Bluffs and St. Joseph Railway on August 18,1868, Council Bluffs was finally linked to St. Louis warehouses on a year-round basis.

Merchants in western Iowa hoped to stimulate competition between merchants in St. Louis and Chicago. Farmers in western Iowa anticipated increased prices for their agricultural products through competitive bidding between the two cities.

At the same time, eastern railroad companies were encouraged to build west quickly to cash in on supplying the Council Bluffs merchants. St. Louis firms were advised to support the construction of rails between that city and Council Bluffs in order to maintain its customers there. Encouragement of this nature was hardly needed, since Council Bluffs was the logical place to link to the Union Pacific Railroad.

Out of a series of mergers, recharters, and consolidations, the Chicago and North Western Railway emerged in June, 1864. Its predecessor, the Lyons and Iowa Central Railway, had disappeared after the panic of 1857 . In July, 1864, the Chicago and North Western was authorized to build from Boone to the Missouri River. The directors of this line probably planned to build to Council Bluffs from the beginning, but wanted to obtain favors, so they remained coy. The Council Bluffs press urged Pottawattamie County to offer inducements.

It is yet an unsettled question whether this road will come down the Boyer to Council Bluffs, or cross the river at De Sota, but we have reason to believe, ... that if a reasonable inducement is offered by Pottawattamie County the road will make its connection with the Union Pacific at Council Bluffs. This road will reach the Missouri several years in ad-

${ }^{45}$ Ibid., August 8, 1867; July 6, 13, 1865; October 31, 1867. 
vance of any other coming across Iowa, and that town upon the river which secures the advantage of its terminus, will derive an impetus therefrom with which rival points will find it difficult to compete. ${ }^{46}$

Grenville Dodge, chief engineer of the Union Pacific, and Thomas C. Durant, vice president of the Union Pacific, used their influence to have the Chicago and North Western build to Council Bluffs. These Union Pacific officials wanted a speedy completion of a year-round supply route so supplies need not be shipped to Omaha via the Missouri River, which was frozen four months of the year. Railroad equipment from Chicago and other eastern points could be shipped to Omaha any time by rail. ${ }^{47}$

Officials of the Chicago and North Western came to Council Bluffs on July 9, 1866 to make a definite proposition. If $\$ 30,000$ and the right of way through the county were donated, the railway would guarantee to build to Council Bluffs. During a meeting on July 9,1866 , this proposition was considered. Stages were erected at either end of Burhop's Hall, one for the band and the other for the guest speakers. Railroad officials, John I. Blair and W. W. Walker, and prominent Council Bluffs citizens were featured speakers. Marshall Turley headed the list of subscriptions with his donation of eighty acres of land for a depot and other railroad buildings. Thirty thousand dollars were donated by various firms: one business firm donated $\$ 2,000$; eleven subscribers pledged $\$ 1,000$ each; other contributors pledged $\$ 100$. D. C. Bloomer felt the large donation was unnecessary, since the railroad directors had always intended to build to Council Bluffs. ${ }^{48}$

Several weeks after the meeting, the Chicago and North Western advertised in the Chicago Times for 5,000 workers to help complete the line to Council Bluffs. The Chicago Tribune predicted that by June 1,1867 , the Tribune would be placed on every breakfast table in Council Bluffs and Omaha on the morning after publication. ${ }^{49}$

In Sepember, 1867, townspeople witnessed ground breaking

${ }^{46}$ Council Bluffs Nonpareil. September 21, 28, 1865.

${ }^{4}$ Stanley P. Hirshson, Grenville M. Dodge (Bloomington: Indiana University Press, 1967), p. 158.

${ }^{48}$ Council Bluffs Bugle, July 19, 1866; Bloomer, op. cit., XI (April, 1873), 441.

${ }^{49}$ Frank P. Donovan, "The North Western in Iowa," The Palimpsest, XLIII (December 1962), 552-5. 
ceremonies for the depot. A similar ceremony the previous January had marked the completion of the line to Council Bluffs. Congratulatory telegrams were read and the director and superintendents of the construction company were honored. Grenville $\mathrm{M}$. Dodge used the occasion to spur the citizens to greater achievements:

\footnotetext{
If we but will it and use the ability, energy, enterprise, and capital we have among us, we can within the next two years-if financial matters pursued prosperous, and no great revolution overtakes our countryconcentrate here five great trunk railroads, that shall bring to and through us the trade and traffic of the North, East, West and South. I therefore appeal to you, today, to awake from this sleep that has possessed us, and each one and all of us determine from this day henceforth to place our shoulders to the wheel, and use all our ability, capital, and enterprise in building up here a city and a railroad centre, that shall be second to none in the State of Iowa, and which shall be the metropolis of the Missouri Valley. ${ }^{\text {so }}$
}

The Chicago \& Rock Island Railroad also began building towards Council Bluffs during the 1860s. It was the parent company of The Mississippi \& Missouri Railroad which had been built from Davenport to Iowa City and surveyed to Council Bluffs by January 1856 . The Civil War halted construction on the road. In December, 1865 , the $M \&$ \& was sold to the Chicago and Rock Island Company. Since Council Bluffs residents had lost their investment in the 1850 s in the $M \& M$, the Nonpareil exulted, "There will be a rattling among the dry bones on this line of the M \& M." The Rock Island, headed for the Missouri, competed with the Chicago and North Western. In the fall of 1867, construction was booming. Some 1,700 men were working, and the company was advertising for 3,000 more. The following elated report was printed in the Bugle.

\footnotetext{
We have so much whistling now, from the locomotives of the Union Pacific, Chicago and Northwestern, Council Bluffs and Sioux City, and the Council Bluffs and St. Joe Railroads that when the Chicago Rock Island and Pacific Railroad gets here, we will hardly discover the accession to the whistling. ${ }^{s 1}$
}

John F. Tracy, president of the Rock Island, used every opportunity to popularize the road. For instance, the editor of the Bugle was invited to ride on the Rock Island special between Des

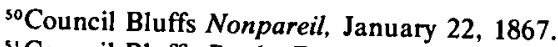

${ }^{51}$ Council Bluffs Bugle, December 19, 1867. 
Moines and Marengo, ninety-two miles east. He boasted about the comfort on the Rock Island.

This road is one of the best, if not the best in Iowa. It is as smooth and level as a 'house floor,' and being constructed with continuous rail . . . that eternal click and jerk heard and felt on roads constructed with rail connected by 'chains,' is not experienced upon it. ${ }^{\text {s2 }}$

On May 12, 1869, the first train of the Chicago, Rock Island and Pacific entered Council Bluffs. Cheering residents were awed when the Rock Island's sensational "silver" (reportedly nickelplated) locomotive arrived from the East. This locomotive had been purchased in Paris where it had been the toast of the 1867 Exposition. The fire company, ladies' societies, brass band and artillery squad participated in the celebration. Part of the celebration included laying the cornerstone of the Ogden Hotel. This hotel, famous for its luxury, was named for William B. Ogden, a Chicago railroad financier.

During the first few months of through service to Council Bluffs, the Rock Island won the approval of the traveling and shipping public for its fast schedules and comfort. The "fast Pacific express" made the run from Chicago to Council Bluffs in eighteen hours and averaged twenty-seven and one half miles per hour. ${ }^{53}$

The Burlington and Missouri was the third railroad to arrive at Council Bluffs from the East. In the fall of 1868 its president, James F. Joy, proposed Council Bluffs for its terminus, if the citizens would donate twenty acres of ground for a depot. Nearly a year later construction was only seventy-five miles away and many were sure it would soon lead into Council Bluffs. President Joy had become a heavy stockholder in the line between Council Bluffs and St. Joseph; and the Burlington and Missouri formed a juncton with that line at Pacific Junction, running into Council Bluffs upon the same track. On December 4, 1869, the first Burlington train entered the city. ${ }^{54}$

After the Union Pacific had been released from its obligation to construct a branch to Sioux City, the Sioux City and Pacific

${ }^{52}$ Ibid., April 16, 1868.

${ }^{53}$ Council Bluffs Bugle, June 17, 1869.

s4 Bloomer, op. cit., XII (January, 1874), 49. 
Railroad Company was organized in August 1864 and began laying track at California Junction. In early 1868 the line was completed into Sioux City. From California Junction the Sioux City and Pacific Railroad was connected to Council Bluffs by the Chicago and North Western, which later acquired a majority of Sioux City and Pacific Company stock.

Promoters and residents had reason to believe that Council Bluffs had succeeded as a town by 1869 . The population had swelled from several thousand in 1859 to 10,020 in 1870 . Two large pork packing plants had been built. A new courthouse had been erected, and business houses "numbered by the hundreds." The dream of being a major staging area serving the needs of the westward-bound emigrants was realized:

There is no necessity now for talking and writing about Council Bluffs as we talked and wrote twelve years ago. The clouds that then overhung our destiny have been removed, and the sun of the city's glory is shining fully upon us and all we have to do is to direct its rays to our advantage and future greatness. ${ }^{s s}$

After an exhaustive campaign, the citizens of Council Bluffs had successfully persuaded five railroads to build to their city. The dream of some ten years earlier of becoming the "Star of the Northwest" was realized.

${ }^{\text {ss Council Bluffs Bugle, January, } 1870 .}$ 
Copyright of Annals of Iowa is the property of State of Iowa, by \& through the State Historical Society of Iowa and its content may not be copied or emailed to multiple sites or posted to a listserv without the copyright holder's express written permission. However, users may print, download, or email articles for individual use. 